NBER WORKING PAPER SERIES

\title{
RENT-SEEKING AND TRADE POLICY: AN INDUSTRY APPROACH
}

Robert E. Baldwin

Working Paper No. 1499

NATIONAL BUREAU OF ECONOMIC RESEARCH 1050 Massachusetts Avenue Cambridge, MA 02138

November 1984

The research reported here is part of the NBER's research program in International Studies and project in Productivity (World Economy). Any opinions expressed are those of the author and not those of the National Bureau of Economic Research. 
NBER Working Paper \#1499

November 1984

Rent-Seeking and Trade Policy:

An Industry Approach

\section{$\underline{A B S T R A C T}$}

The model of rent-seeking presented in this paper is consistent with the observation that labor and management in an industry almost always adopt the same position concerning the desirablitty of import protection versus trade liberalization. The paper also discusses the size of the returns to rent-seeking relative to the costs of lobbying, factors influencing the type of government assistance sought by an industry, and ways in which the benefits and costs of protection can be made more widely known to both the industries concerned and the general public.

\footnotetext{
Robert E. Baldwin

Department of Economics University of Wisconsin Madison, WI 53706
} 


\title{
RENT-SEEKING AND TRADE POLICY: AN INDUSTRY APPROACH
}

Robert E. Baldwin, University of Wisconsin-Madison

\author{
Executive Summary
}

Trade economists have had difficulty in explaining why labor and management in the same industry invariably share the same view concerming the desimability of import protection versus trade liberalization for their industry. The standard trade model gives the result that the economic interests of these two groups are opposed to each other: if trade liberalization raises the real income level of capital owners, it will lower the real income level of workers, and vice versa. A model with sector specific captal that is often used in analyzing shopt-run trade issues demonstrates that it is possible fom the real incomes of capital and labor in the same industry to move in the same direction but this is not a general conclusion. However, by modifying this model to take into account an important feature concerning the nature of labor's earnings, one is able to derive the real world result that the shortwrun economic interests of labor and mangement in any industry are in harmony rather than conflict with regard to trade polioy.

The modification involves recognizing that not on ly does the income accruing to capitalists take the form of a rent due to the sector speciticity of capital, but part of the income earmed by labor is a rent because of the industry specific nature of labor skills. Several empirical studies tracking the earnings profite of workers displaced by import competition indicate that when these workers do find new jobs their wages are often as much as 10-25 percent lower that in their old jobs. One important reason is that some of their skilis are worthless in mew industries, and they must to some extent begin as unskitied wonkers in their new jobs. They gradual7y acquire new skills through on-the-job training but it ma take several years before their wages are comparable to workers who have spent many vears in this industry. 
Qeouse of the rent aomponent in thetr wages workers wil acoept sorie meduction in imcome in the ir intetat jobs before seaking new opportuntwis, prowided wases in the industur wre flexible. However. they will then join with management to pass the government for moont protection in order to ratse the prioes of the goods they produce and regati at leas part of therr rents. When wages are rigid due for example, to a bage contract, the situation is more complex. However, the threat of further job Tosses from continumg import competition is 7 ikely to cause even those who have not been displaced to join those who have in Tobbying for import controts.

crude estimates of themagnitude of rentat inoomes at stake in typicit industries and of the oosts to the private sector of petitioning for protection under U. S. trade laws sugest that the rate of return on these activities is very high and may acount in pert for the inomensed protectionist activity in recent years. The paper proposes thet certain changes be made in the procedures whereby industries are granted protection. They are designed to make them more transparent and to provide more informetion on the effects of protection on other industries. consumers, and the balance of trade. 


\section{RENT-SEEKING AND TRADE POLICY: \\ AN INDUSTRY APPROACH \\ Robert E. Baldwin \\ University of Wisconsin-Madison}

\section{Introduction}

In recent years economists have modeled the process by which particular industries and income groups seek protection against import competition through lobbying and bloc voting (see, for example, Baldwin [1976; 1982], Brock and Magee [1980], Bhagwati [1980], Findlay and Wellisz [1982], and Mayer [1983]). The earliest theoretical work on the subject is the classic paper by Stolper and Samuelson [1941] in which the authors demonstrate that in a standard two-good, two-factor Heckscher-Ohlin model, the factor used intensively in the importcompeting sector will gain in real income terms from protection whereas the other factor will lose. Unfortunately, the Stolper-Samuelson theorem does not seem to be very useful for understanding the nature of present-day protectionist pressures. As Magee [1980] found in analyzing testimony given during the Congressional hearings on the 1974 U.S. Trade Act, representatives of labor and capital from the same industry almost always take the same position concerning the desirability of granting the President the authority to undertake another trade-liberalizing multilateral negotiation. The divergence in views on the issue of further trade liberalization is along industry lines rather than between capital and labor.

For earlier years, when arguments such as the need for tariffs to maintain labor's standard of living were widely accepted (more, it seems, on grounds of political ideology than of economic analysis), the Stolper-Samuelson relationship may be useful in interpreting tariff history. However, modern economists appear to have been reasonably successful in convincing most political leaders of the fallacy of the pauper-labor argument and of similar arguments 
for protection. To obtain import protection today, it seems to be necessary (but not sufficient) for an income group or industrial sector to demonstrate to the satisfaction of government officials and the public generally that the industry is being injured due to increased imports or to unfair trade practices by foreign suppliers, in the sense these concepts are defined in the General Agreement on Tariffs and Trade (GATT) and national legislation. Import injury (or the threat of injury) is defined in these documents as a short-run phenomenon resulting from such conditions as the significant idling of productive facilities, significant unemployment or underemployment, and rising inventories. Furthermore, any relief provided in the form of higher tariffs, quotas, adjustment assistance, and so forth is generally specified as being only temporary. Consequently, a short-run economic model such as the one formulated by Mayer [1974] and Mussa [1974] seems more appropriate than the long-run Heckscher-Ohlin model for analyzing the particular protectionism that characterizes the nature of recent trade policy history. ${ }^{1}$

In the Mayer-Mussa specific-factor model, it is assumed that the stock of capital is fixed in each of the economy's two production sectors while the third factor, labor, is mobile between the two sectors. ${ }^{2}$ As Mussa [1974] demonstrates, under these conditions an increase in the relative domestic price of one of the two goods (due, for example, to an increase in the duty levied on imports) increases the real income of the specific factor employed in this import-competing sector and reduces the real income received by the owners of capital in the export sector. The real rewards to the labor employed in both sectors may increase or decrease. Since per worker relative wages increase less than the relative price of the protected product, the real income level of labor in both sectors declines when measured in terms of the protected commodity but 
increases when measured in terms of the other commodity. Whether the net result is an increase or decrease in labor's real income depends upon the proportions in which the two goods are consumed.

This impact of protection on labor is also not consistent with Magee's findings concerning the position of labor and capital in each sector on the liberalization-versus-protection issue. For example, if labor gains, both labor and capital in the protected import-competing sector will both favor protection but labor and capital in the export sector will disagree on the desirability of protection.

One model that does yield results consistent with Magee's findings is, as Magee [1978, p. 138-39] points out, Cairnes' [1874] noncompeting-groups model in which all productive factors are industry-specific. However, this framework is inconsistent with what several studies of workers displaced by import competition indicate, namely, that a high proportion of permanently displaced workers do move to other industries to obtain employment. (See, for example, Richardson [1982, p. 334]•)

What these studies also show, however, is that workers permanently displaced from an industry due to import competition generally suffer a significant loss in earnings, both because of the search time involved in obtaining another job and because of the lower level of earnings in their new jobs. ${ }^{3}$ An important reason for this decline in earnings is that industry-specific skills acquired by workers through learning-by-doing are worthless when the workers transfer to another industry. Consequently, because of the threatened loss in the rents earned on sector-specific human capital, workers in an industry facing increased import competition join capitalists in the same industry, who also are threatened wth a loss in rents from their sector-specific physical capital, in seeking protection against the increased import competition. 
II. A Model of Rent-Seeking Through Protection

This rent-seeking behavior of workers and capitalists can be analyzed with the following two-commodity, specific-factors, small-country model. Assume there are fixed stocks of sector-specific physical capital, capital in sector X, and capital in sector $Z$. There is also a given supply of labor, part of which has acquired unique skills for producing commodity $\mathrm{X}$ and the rest of which has acquired unique skills for producing commodity $Z$. Initially it will be assumed that these two types of labor are fully employed in the sectors for which they have special skills and that wages are equal for the two types of labor. Unlike physical capital, labor is assumed to be mobile between the two sectors in the short run. However, when skilled workers from elther sector move to the other sector, their productivity level is only a certain fraction of that achieved by skilled labor.

This situation is depicted in Figure 1, which is a modified version of Mussa's (1974, p.1194) diagrammatic representation of the specific-factors model. The horizontal axis indicates the total fixed labor supply for the economy, with the quantity of labor employed in sector $X$ being measured to the right from $O_{x}$ and the quantity employed in $Z$ being measured to the left from $O_{z}$. The vertical axis measures the value of the marginal productivity of labor in sectors $X$ and $Y$ (measured from $O_{X}$ and $O_{z}$, respectively) in terms of units of $Z$ per unit of labor. At the given initial price of $X$ in terms of $Z$, the curves VMPL ${ }_{x S}\left(P_{x}^{0}\right)$ and VMPL ${ }_{z s}$ show the value of the marginal productivity of skilled labor in sectors $X$ and $Z$ as successive units of only this type of labor are employed in each sector. The intersection of the two curves at $A$ indicates the assumed initial long-run equilibrium point where $o_{x} L^{0}$ of labor has been employed in sector $X$ for sufficient time to acquire the unique skills used in producing this 
5

Figure 1

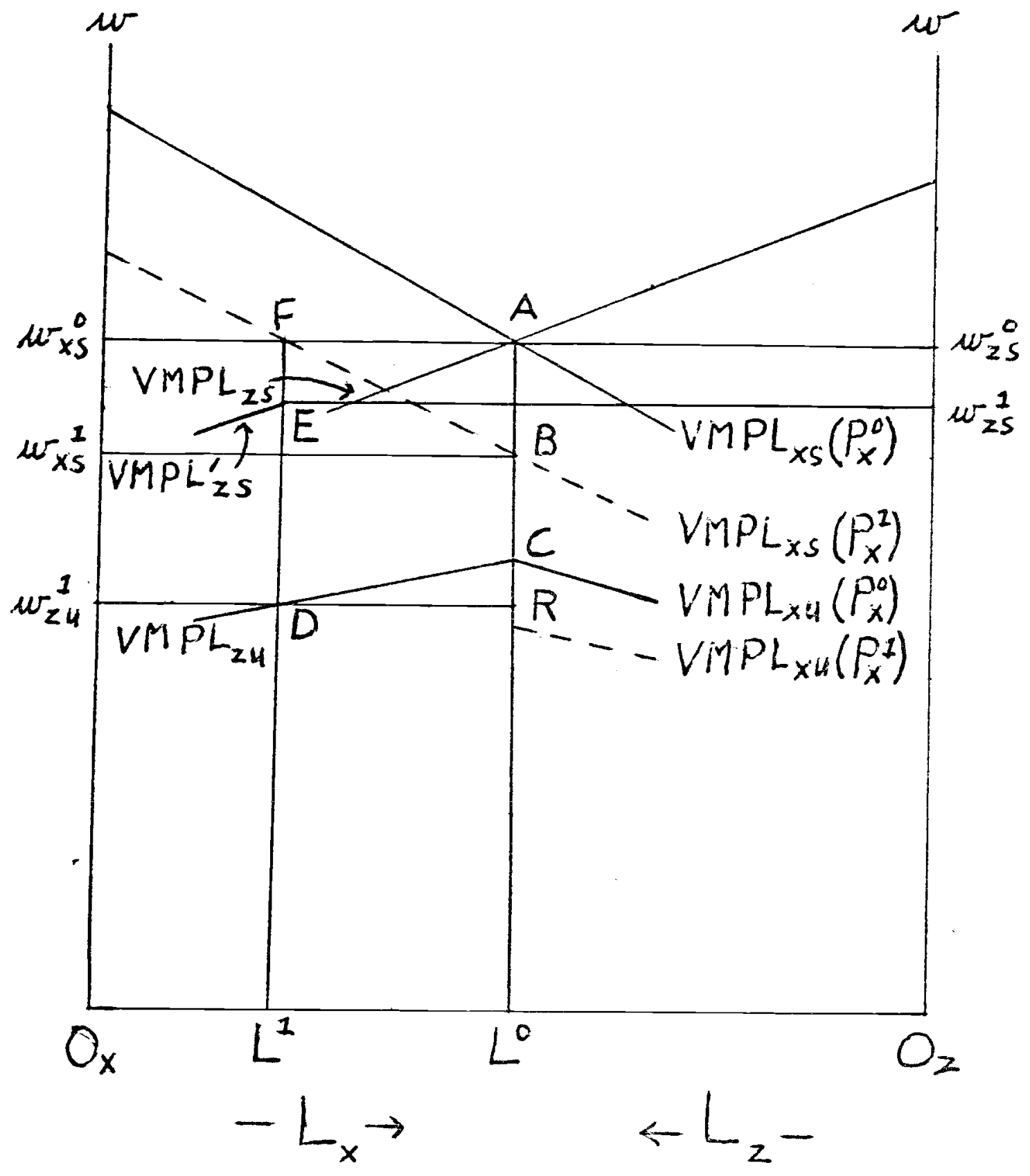


commodity, and the $\mathrm{O}_{z} \mathrm{~L}^{\mathrm{O}}$ of labor employed in producing $\mathrm{Z}$ has also been similarly trained. Since perfect competition is assumed, the wage in each sector is equal to the value of the marginal productivity of the skilled labor employed in each sector. The wages of skilled labor in sector $x, 0_{x} w_{x s}^{\circ}$, and in sector $z$, $0_{z} w_{z s}^{\circ}$, are equal because the long-run equilibrium is one in which sufficient time has elapsed for labor to shift from one sector to the other and acquire the latter sector's specialized skills. 4

The curve labeled VMPL ${ }_{z u}$ that begins at the point $C$ on the vertical line $\mathrm{AL}^{\circ}$ indicates what the value of the marginal productivity of skilled labor displaced from sector $X$ would be when this labor is employed as unskilled labor in sector $Z$ in addition to the $O_{z} L^{\circ}$ of skilled labor already employed in the $Z$ sector. Similarly, the curve VMPL ${ }_{x u}\left(P_{x}^{0}\right)$ depicts the schedule of the value of the marginal productivity of labor displaced from sector $Z$ and employed in sector $X$ in addition to $O_{x} L^{\circ}$ of skilled labor employed there. Both of these curves are assumed to be some (not necessarily equa1) fraction (less than one) below the marginal productivity schedules of skilled labor in these two sectors. 5

Now suppose the initial long-run equilibrium situation is disturbed by a fall in the price of commodity $X$ because of increased import competition. The curves VMPL ${ }_{X S}\left(P_{x}^{1}\right)$ and VMPL ${ }_{x u}\left(P_{x}^{1}\right)$ are determined by multiplying the physical marginal productivity schedules of skilled and unskilled labor employed in sector $X$ ( $i$ in the previously described manner) by this lower price of $X$ in terms of Z. Since the curve $\operatorname{VMPL}_{x s}\left(\mathrm{P}_{\mathrm{x}}^{1}\right)$ intersects the vertical line $\mathrm{AL}_{\mathrm{o}}$ between the points $A$ and $C$, there will not be any reallocation of labor between the two sectors; $\mathrm{O}_{z} \mathrm{~L}_{\mathrm{O}}$ of skilled labor will remain employed in sector $\mathrm{Z}$ and $\mathrm{O}_{\mathrm{x}} \mathrm{L}$ of skilled labor in sector $X$. However, the wage of the skilled labor in $X$ will decline to $0 x^{1} w^{1}$ as part of its rents are transferred to consumers. Similarly, the rents collected by capitalists in sector $X$ will decrease from the area of the 
triangle above the line ${ }_{x s}{ }_{A}^{A}$ and under the VMPL ${ }_{x s}\left(P_{x}^{0}\right)$ line to the area of the triangle above the line ${ }^{1}{ }_{x s} B$ and below the $\operatorname{VMPL}_{x s}\left(P^{1}\right)$ Iine. The skilled labor employed in sector $Z$ continues to receive a wage of $\mathrm{O}_{z} w_{z s}^{\circ}$, while capitalists also continue to receive a rent on their capital equal to the area above the line $\mathrm{Aw}_{\mathrm{zS}}^{\mathrm{o}}$ and under the VMPL $\mathrm{zs}$ line. ${ }^{6}$

The real income of workers and capitalists in sector $X$ measured in terms of commodity $X$ remains unchanged, since their income measured in terms of good $\mathrm{Z}$ decreases by the same proportion as the price of $X$ in terms of $Z$ decreases. However, since the price of $z$ in terms of $i$ tself is unchanged, labor and capital in sector $X$ incur a reduction in their real income measured in terms of good $z$. Thus, as long as both groups consume some of commodity $Z$, both groups suffer an unambiguous reduction in their real income level. Since the returns to labor and capital in sector $Z$ remain unchanged when measured in terms of $z$, these groups enjoy an unambiguous increase in their economic welfare, since the price of $X$ falls. If we think of sector $X$ representing a particular industry and sector $Z$ representing a composite of many industries, one can appreciate why labor and capital in sector $X$ are likely to lobby the government vigorously for import protection that will raise the price of $\mathrm{X}$ back toward its initial level. With a price rise they will benefit significantly from the increase in rents that will accrue to them. On the other hand, the decrease in real income for the typical worker or capitalist employed in the rest of the economy is likely to be too small to warrant counter-lobbying efforts by these individuals.

An alternative to assuming that wages are flexible in sector $X$ is to assume they are fixed in the short run at $0_{x} w^{0}$, due, perhaps, to a collective bargaining contract on wages that holds throughout the time period. Consequently, in response to the price decline in sector $X$, firms will lay off $L^{\circ} L^{l}$ (=AF) skilled workers in this sector. These workers will be forced to shift to sector $z$ and 
take jobs as unskilled workers. Their marginal productivity schedule as they supplement the skilled workforce already employed in the $Z$ sector is indicated by the VMPL ${ }_{z u}$ curve originating at the point $c$. Their wage will be $0_{x} w_{z u}^{1}$. Furthermore, the possibility of firms substituting unskilled workers for skilled workers will drive the wage of skilled workers in this sector down to $0_{z} w_{z s}^{1} .^{7}$

The skilled workers still employed in sector $X$ gain in real income terms since their wage in terms of $Z$ remains unchanged when the price of commodity $X$ declines. The workers displaced from sector $\mathrm{X}$ who end up as unskilled employees in sector $Z$ suffer an income loss in terms of $Z$ equal to the area FARD. They also lose in terms of commodity $X$ since the proportion by which their wages decrease, that is, $\mathrm{FD}_{\mathrm{FL}}{ }^{1}$, is greater than the proportion by wich the price of $\mathrm{X}$ declines, that is, $\mathrm{AB} / \mathrm{AL}^{\circ}$. As long as these workers continue to belong to the labor union in sector $X$ and there is a threat of continued price decreases in this sector due to import competition, the workers employed in $\mathrm{X}$ are likely to be willing to use part of their earnings to lobby for import protection for this sector. They will be joined by the owners of capital in sector $X$ since their rent declines to the area above the line ${ }_{x s}^{0} F$ and below the VMPL ${ }_{x s}\left(P_{x}^{1}\right)$ curve. This decline is relatively greater than the decrease in the price of $X$ and thus represents an unambiguous drop in real income.

The rental return accruing to capitalists in sector $Z$ increases to the area under the VMPL ${ }_{z s}$ curve but above the $\mathrm{Ew}_{z s}^{1}$ line and to the right of the line from $A$ to $B$ plus the area CRD. Since the price of $X$ has declined, this increase represents a real income increase measured in terms of either commodity. Skilled workers in sector $z$ lose in terms of commodity $z$ since their wage in terms of $z$ declines to $O_{z} w_{z s}^{1}$ and could either gain or lose in terms of commodity $x .^{8}$ 
Figure 2, which is a redrawing of the essential parts of Figure 1, shows the effect of a greater decline in the price of commodity $X$. Now the new marginal productivity curve for skilled workers in sector $X, V_{M P L}\left(P_{x}^{2}\right)$, intersects the marginal productivity curve for unskilled workers in sector $\mathrm{Z}$ at $\mathrm{G}$ rather than intersecting the vertical line $\mathrm{AL}^{\circ}$ between points $\mathrm{A}$ and $\mathrm{C}$. This means that $\mathrm{GH}$ of skilled workers initially employed in sector $X$ are displaced and forced to obtain jobs as unskilled workers in sector $z$ at a wage equal to $0_{z} w^{2}$. Moreover, the wage of the remaining skilled workers in sector $X$ is also driven down to $0_{x} w_{x s}^{2}$ and they lose all the rent derived from their specialized skills for this sector. The wage of skilled workers employed in sector $z$ is also driven down to $0_{z} w^{2}$

Since the relative decline in the price of $X, A K / A L_{0}$ is greater than the relative decline in wages in sector $X$ as well as in the wages of workers formerly employed in sector $\mathrm{X}, \mathrm{AH} / \mathrm{AL}^{\circ}$, the real income of those still employed in $\mathrm{X}$ as well as the newly employed $z$ workers increases in terms of commodity $X$ but declines in terms of commodity $z$. Skilled workers in sector $z$ also gain in terms of $X$ and lose in terms of $z$. In contrast, capitalists in sector $X$ lose in terms of both commodities whereas capitalists in $\mathrm{Z}$ gain in terms of both commodities.

\section{Protection-Seeking}

If capitalists and workers in industry $X$ lose in real income terms (or fear they will lose in the future) and are able to overcome the free-rider problem asociated with the collective-good nature of import protection, they will organize into a common interest group, raise funds through "voluntary" contributions, and seek protection or some other form of assistance from the government. In doing so, they will maximize their gains from these efforts by collecting and spending funds up to the point where the additional cost of 
Figure 2

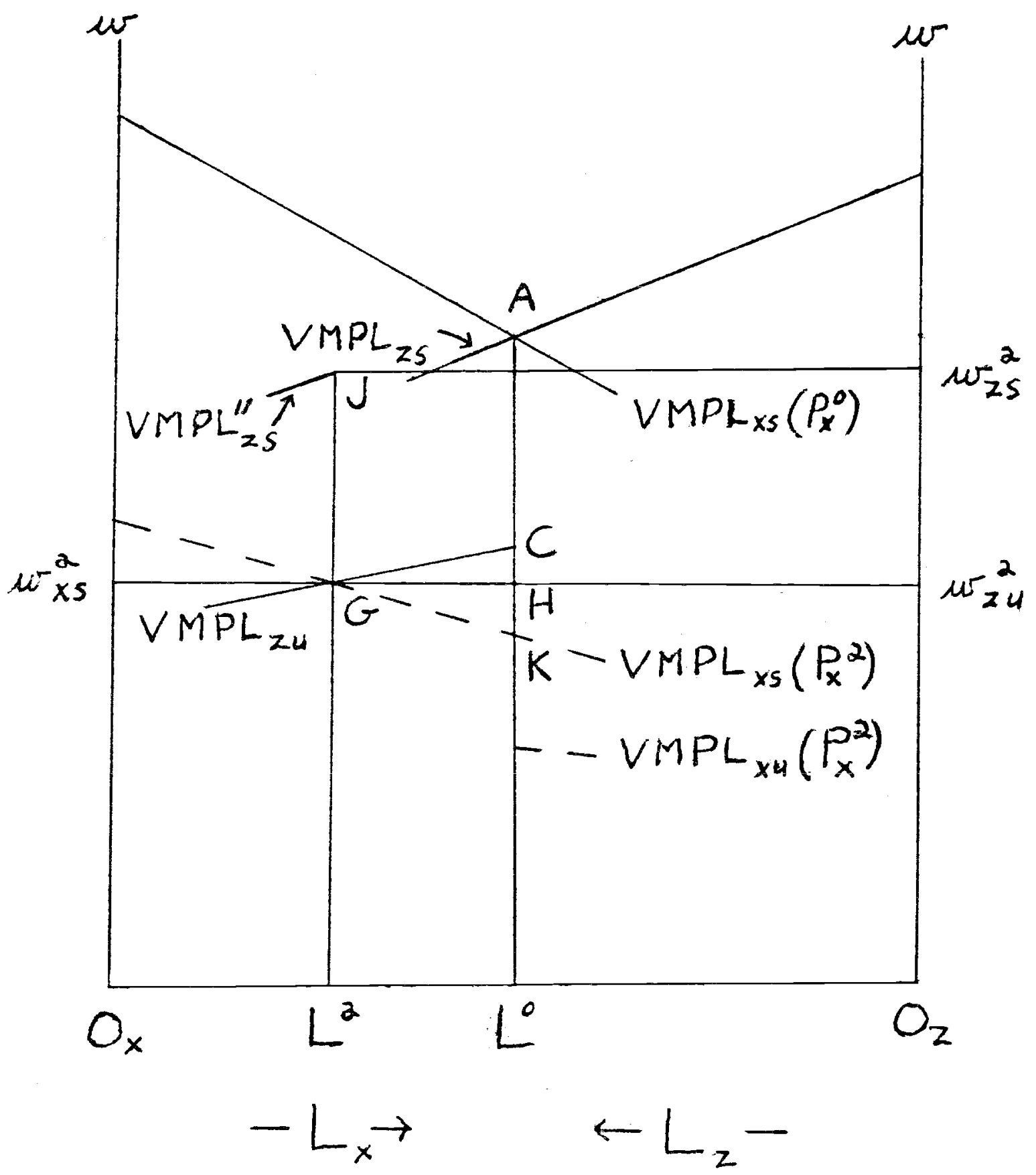


their protection-seeking activities equals the additional income benefits from further protection.

Since the tariff-seeking process involves the expenditure of real resources, the effect of this lobbying activity on economic welfare is of interest. Suppose that skilled labor and physical capital in sector X (the importcompeting sector) can be used for lobbying purposes. In terms of Figure 1 , the employment of physical capital for this purpose lowers the marginal productivity curve fot labor in sector $X$, while the utilization of this sector's skilled labor for lobbying shifts the origin $0_{x}$ to the right and causes the marginal productivity of labor curve to shift to the right in a parallel fashion. As long as the equilibrium labor distribution point remains between points $\mathrm{A}$ and $\mathrm{C}$ so that the output of $\mathrm{Z}$ is unchanged while the output of $\mathrm{X}$ declines, the lobbying will reduce the economy's output of $X$ and $Z$ valued at free trade prices. In other words, the lobbying activity will always be welfare-reducing.

If, however, sector X's marginal productivity curve for skilled labor intersects sector Z's labor productivity curve for unskilled labor in the downwardsloping part of this curve (as in Figure 2), so that the output of $\mathrm{Z}$ increases as the output of $X$ declines, then, as Findlay and Wellisz (1982) point out, the outcome first noted by Bhagwati and Srinavasan (1980) is possible. The output of $X$ and $Z$ valued at international prices can be greater under import protection that is gained through resource-using lobbying activities than under the same level of protection but in a situation where no resources are expended in obtaining this protection.

IV. The Size of the Stakes in Protection-Seeking

In Figure 1 and 2 the area under labor's marginal productivity curve for sector $X$ indicates, of course, the value added by labor and capital in this 
sector at a particular price of $\mathrm{X}$ and employment level in the sector. The magnitude of the value added by these two productive factors in some of the industries that have sought protection can be obtained from national input/ output tables. For example, the 1972 U.S. input/output table prepared by the U.S. Department of Commerce (1979) shows the value added by labor and property in the motor vehicles and equipment sector to be $\$ 20.7$ billion; in the apparel sector $\$ 10.1$ billion; and in footwear and other leather products $\$ 1.9$ billion. This means that if the prices of the goods produced in these sectors fall by 1 percent because of greater import competition, the short-run income of these factors will, as previously explained, fall by 1 percent. This amounts to $\$ 207$ million in motor vehicles, $\$ 101$ million in apparel, and $\$ 19$ million in footwear. Value-added data for some of the smaller industries that have petitioned for protection can sometimes be estimated from information published in reports of the U.S. International Trade Commission (ITC) on import injury cases. For example, 1 percent of the 1982 value added by labor and capital employed in the stainless steel and alloy tool steel industry was approximately $\$ 9$ million, in contrast to only $\$ 145$ thousand in the industry producing tubeless tire valves.

If these are the rents that can be obtained by labor and capital with a protection action that raises the prices of the products supplied by these sectors by 1 percent, what are the costs of seeking protection? John Jackson (1984) estimates that the U.S. system for the regulation of imports through the dozen or so different formal types of procedure cost the private sector about $\$ 40$ million in 1982 and the government $\$ 200$ million. The number of such cases in which government determinations were made or were pending in 1982 were: escape clause cases, 4; preliminary and final anti-dumping decisions, 61 and 10, respectively; preliminary and final countervalling duty decisions, 111 and 13 , 
respectively; unfair trade cases, 15; and cases alleging unfair or unreasonable trade practices by foreign governments, 19.

What the comparison of these value-added and cost figures seems to indicate is that, even without expressing all the value-added figures in 1982 prices or capitalizing the gains over the period for which the protection is designed to increase value added, the possible benefits are very large compared to the costs. As Adams and Dirlam (1984) emphasize, the cost side is favorable to protection petitioners who utilize the established administrative channels because the government pays most of the costs involved. Furthermore, as ITC cases indicate, downward price pressures of 5-10 percent or more due to increased import competition are not at all unusual.

\section{Alternative Measures for Capturing Rents}

Thus far 1 t has been assumed that the industries being considered lobby for protection against imports. However, this leaves open the particular form of import protection and ignores the fact that some industries seek various forms of government subsidization as an aid to competing in international markets. Obviously, a general determinant of the type of assistance sought by an industry is the nature of $i$ ts balance of trade. An import-competing industry will seek protection against imports in such forms as tariffs, while an export-oriented sector will press for export subsidization through such means as subsidized export financing and special export-related tax benefits. Both types of industries will lobby the government for domestic subsidies such as access to capital funds at below-narket interest rates or an outright grant.

Import-competing industries generally prefer quotas over tariffs on the grounds that their effects are more predictable. A tariff increase may be offset by lower foreign prices as foreign suppliers accept lower profits or continue 
tinue to lower their unit costs. Some government officials also prefer quotas since with orderly marketing agreements and "voluntary" export restraints, the government can apply protection selectively and thus avoid complaints or possible retaliation by countries whose exports to the protecting country have not increased. Well-established foreign firms also often favor quotas over tariffs since they usually reap most of the windfall galns and need not be as concerned with their new or rapidly expanding domestic competitors. However, the protected domestic industry often finds that the quotas do not have the expected restrictive effect due to quality upgrading and increased imports from third countries. As a result of these responses, industries often follow a pattern of protection-seeking that involves progressively more restrictive means, for example, more and more bilateral quota agreements, as in the case of textiles and apparel, or domestic content requirements, as in the case of the U.S. automobile industry.

Within recent years more and more U.S. import-competing industries have sought protection under the laws dealing with such "unfair" trade practices as foreign dumping, foreign subsidization, and market disruption. The anti-dumping, countervailing duty, and market-disruption laws have a much weaker injury requirement than the traditional "escape clause" route for securing protection. Furthermore, it is easier to rally public support for protection on grounds of unfair actions by foreign suppliers than on the basis of injury that might be caused by inefficient management of the domestic industry. Again, the countryspecific nature of the protective response also appeals to some government officials.

Government subsidies directed only at an industry's exports are more difficult to obtain for an industry than import protection, due to the explicit 
GATT ban on export subsidies. However, subsidized export credits are permitted provided the government is a signatory to an international undertaking on official export credits, such as the one operated under OECD auspices. Special tax breaks for exporting firms are also allowed under certain conditions, although the Domestic International Sales Corporation legislation of the U.S. was declared to be in violation of the GATT export-subsidy rule. Consequently, lobbying by export-oriented firms in the developed countries usually is aimed at both of these forms of export subsidization.

Assistance that does not distinguish between exports and output destined for domestic consumption is sought by both export-oriented and import-competing industries. The variety of domestic aids is also wider than the assistance to export-oriented industries because GATT rules in this area are much less wel1defined than in the export field. This type of aid includes general loans at below-market interest rates, the provision of equity capital, accelerated depreciation allowances, tax holidays, government financing of needed infrastructure investment, wage subsidies, etc. While I do not know of any empirical work on the subject, one would expect that workers prefer import protection, export subsidization, and wage subsidies over capital subsidies. The modernization of capital facilities generally associated with such subsidies is more likely to be labor-displacing rather than labor-using.

An alleged drawback of most forms of subsidization is that they appear as a cost item in the budget, whereas tariff protection, for example, is actually a revenue-producing activity. This drawback, however, does not appear to have been very effective in restraining the extensive subsidization that some countries undertake. When an export-oriented industry suffers injury due to loss of foreign markets, it is just as difficult to refuse adjustment assistance 
in the form of subsidies than to deny tariff assistance to an injured importcompeting industry. Moreover, it is apparent to all what the adverse effects will be from cutting off a subsidy, whereas because of its uncertain effects, it can be argued that eliminating a tariff may not hurt an industry at all.

\section{Rent-Seeking Due to Protection}

The analysis thus far has focused on the process by which increased import competition in an industry may lead to lobbying by the industry for import protection. However, economists, for example, Krueger (1974) and Bhagwati and Srinivasan (1980), have also modeled the manner in which import protection leads to lobbying for the windfall gains or tariff revenue associated with the protection. As Anne Krueger (1974) pointed out in her pioneering article on rent-seeking, when there is a system of binding quantitative restrictions in which the right to import depends on the possession of an import license, resource-using competition is likely to arise among importers for the windfall gains associated with the ownership of import licenses. This can range from investment in excess capacity in order to obtain a larger share of import licenses to lobbying or actually bribing government officials who make the allocative decisions.

In most instances when developed countries enter into agreements with other countries that quantitatively limit imports from these countries, the governments of the exporting countries are given the right to allocate the quotas among their domestic producers. ${ }^{9}$. In these cases foreign producers lobby their governments for the rents attached to the right to export. For example, under the Japanese voluntary export restraints on auto exports to the United States, the smaller auto producers in Japan have lobbied their government for a larger share of the export quotas. 
Bhagwati and Srinivasan (1980) introduce the term, revenue-seeking, to describe the situation in which economic agents lobby for a slice of the tariff revenue resulting from the adoption of protective tariffs. This case is somewhat different from the rent-seeking analyzed by Krueger (1974). When quantitative restrictions (QRs) are applied to all imports or just to imports of a single sector, the government must devise a system to allocate the rights to import (or export) among traders and producers. Since holders of rights to import specified amounts of a commodity subject to QRs can earn a premium by purchasing the commodity at a lower price than they sell it for, competition wil1 arise among importers for these rights to import.

Under a tariff arrangement the allocation of imports is carried out via the price system, with the tariff revenue usually going automatically into the public treasury in the same way as any tax revenue. Generally, neither customs officials nor any other government officials associated with the importation process have the authority to allocate the tariff proceeds among particular economic agents. The distribution of government revenues customarily involves a decision process by the legislature and chief executive that is only loosely related to their revenue-raising decisions. Consequent1y, the many different groups lobbying for government allocative decisions favorable to their interests usually do so without regard to any particular tax source.

One revenue situation that is likely to intensify competitive lobbying activity is a substantial rise in tax revenues that is unrelated to increased government spending plans. This could come about because, for example, of an appreciable rise in protective tariffs on most imports. As Bhagwati and Srinavasan (1980) point out, various interest groups will then lobby government officials for a share of these extra revenues. However, when the protective 
tariff for only a particular industry is increased, the increment in tax revenue is likely to be too small to trigger increased lobbying activity aimed at obtaining a part of this extra revenue. The extra tariff proceeds tend to become part of the country's general tax revenues, and they are spent for purposes that do not require separate spending decisions by the legislature or chief executive.

Sometimes particular tax revenues are earmarked for specfic distribution purposes. For example, state gasoline taxes are often regarded as user fees and only utilized for the maintenance and expansion of the highway system. Presumably, this arrangement is the consequence, at least in part, of lobbying by groups representing truckers and private automobile users.

Recently, Hufbauer and Rosen (1983) have proposed earmarking tariff revenues generated by escape clause tariffs to aid the impacted domestic industry to adjust to the changed comparative-cost conditions. Feenstra and Bhagwat1 (1980) have also analyzed the effects of using tariff proceeds to increase the incomes of workers in protected industries and thereby influence the amount of tariffseeking lobbying by these groups. However, as yet there does not seem to be much evidence that workers and capitalists in such industries have lobbied for these revenues or for the release of other existing revenues on the grounds that there has been a net increase in government revenues. They do, of course, often lobby for government assistance beyond the increase in their incomes due to increased tariffs, but this does not appear to be related to the increase in the government's tax revenues.

VII. Controlling Rent-Seeking Behavior

As the cost and benefit figures cited earlier indicate, the incentives for workers and capitalists in industries faced with injurious foreign competition 
in domestic or foreign markets to seek import protection or subsidization are extremely strong. Since the U.S. government bears most of the investigatory costs, even relatively small industries find it worthwhile to petition for import relief through the various administrative channels where such agencies as the International Trade Commission (ITC) and the Commerce Department determine the outcome of petitions for protection on the basis of criteria established by law or administrative regulation. Where small industries are at a distinct disadvantage, however, is in seeking protection via the political route. This involves bringing direct political pressure on the President and Members of Congress so that the President will take the lead in negotiating with foreign countries such arrangements as voluntary export restraints and orderly marketing agreements. As Hufbauer and Rosen (1983) point out, only five U.S. industries have been successful at this level: textiles and apparel, steel, automobiles, meat, and sugar. Collectively, these industries account for over 25 percent of U.S. imports.

In considering the decisions reached in the 53 import relief cases on which the ITC has made findings since 1975, one can only conclude, I think, that protection via this route has been kept reasonably under control. Of these 53 cases the ITC determined that serious injury had occurred as the result of increased imports in 28 instances or 57 percent of the total number. In addition, in 3 cases the vote of the Commission was evenly split. Of these 31 cases sent to the President for final determination, import relief was granted in only 13 of the cases. In 6 other cases the President provided adjustment assistance to the workers, while for the remaining 12 he turned down assistance in any form. Thus, in only 13 of 53 cases, or 25 percent of the total, did the industries alleging serious injury receive assistance in the form of higher tariffs or quotas. 
The major part of the increase in protectionism in the United States has occurred not via administrative channels but as a consequence of industries exerting political pressure on elected officials, of ten, as in the auto case, after their petitions have been rejected by government agencies such as the ITC. Of course, no one would want to block the use of the political route, since the avallability of this avenue of expression is essential for a democracy. Consequently, relying on such a solution as making lobbying too expensive for any industry to undertake is not appropriate. However, it is also important for a democracy that the full implications of protection on the economy as a whole be made known to political leaders and the public generally. At the present time the ITC considers the effects of increased imports and of temporary import relief only on the workers and capitalists in the petitioning industries. The real income implications of increased protection on consumers or employment and trade in other sectors is ignored. When a case goes to the President, an inter-agency committee considers these effects, but this is not made available to the general public. Thus, when industries seek protection via the political route after they fail to obtain import relief through the ITC route, political officials and the general public tend to know about only one side of the case.

One suggestion for providing a more balanced economic evaluation of the ITC's recommendations to the President for increased tariffs or quotas is to require the Commission also to include an evaluation of the probable economic effects of these protectionist recomendations. ${ }^{10}$ This evaluation would include such economic effects as the likely magnitude of the price increases to final consumers on the products covered, the increased costs to other producers using the products as inputs, the expected employment changes in the protected 
industry as well as in sectors using the products as inputs, and the likelihood that the injured industry can become competitive again.

Just as the findings of the ITC with regard to injury are widely disseminated to political officials and the public through various media channels, their assessment of the probable economic effects would also become widely known. This would make it easier for public officials to render political decisions that take into account not only the welfare of workers and capitalists in the injured industry but the welfare of others affected by import protection. 


\section{FOOTNOTES}

1. Jones (1971) also developed a two-product model with two sector-specific factors and one mobile factor but used it to analyze long-run trade issues. Earlier, Haberler (1936, ch. 12) outlined the effects of the existence of specific factors on a country's production possibilities curve.

2. Other properties of the model are that the production function for each of the two commodities is linear homogeneous with declining marginal physical products for each factor, that the aggregate supply of labor is fixed, and that perfect competition prevails.

3. The study in which Richardson (1982) participated found that three years after being permanently displaced by import competition, the average weekly wage of workers was only 92 per cent of their preseparation wage. Another study (Jacobson, 1978) indicated that between the third and sixth year after displacement, workers in such sectors as automobiles, steel, meat packing, aerospace, and women's clothing earned about 15 per cent less than prior to displacement. Still another study (Neumann, 1979) places the wage reduction at about 20 per cent.

4. However, a skilled worker who shifts from one sector to the other is assumed to lose the first sector's skills by the time he acquires the other sector's unique ski11s.

5. For simplicity it is assumed that skilled and unskilled labor are perfect substitutes for each other in production in the same fixed proportion in each sector, for example, 1.5 unskilled workers equal 1 skilled worker. In the long-run the unskilled labor productivity curves will shift up to the skilled labor curves for the two sectors as the unskilled labor acquires the unique skills through learning-by-doing. 
6. In the long run, as skilled workers in both sectors retire and are replaced by young unskilled workers, enough new workers will go into sector $Z$ that the new long-run equilibrium will be where the VMPL ${ }_{z s}$ curve intersects the new schedule of the value of the marginal productivity of labor in sector $x$, namely, the VMPL $x \mathrm{xs}_{\mathrm{x}}\left(\mathrm{P}^{1}\right)$ curve.

7. Employing $\mathrm{L}^{0} \mathrm{~L}^{1}$ unskilled workers in the $\mathrm{Z}$ sector in addition to the $\mathrm{O}_{Z} \mathrm{~L}^{\circ}$ skilled workers drives down the marginal productivity of skilled workers to the point where it equals the marginal productivity of the unskilled workers, namely, $L^{1} D$, multiplied by the assumed ratio for the productivity of a skilled worker compared to that of an unskilled worker, for example, $1.5 \times L^{1} \mathrm{D}$. The curve VMPL' indicates the marginal productivity of skilled zs

labor in sector $z$, given the employment of $0_{z} L^{\circ}$ of skilled labor and $L^{\circ} L^{1}$ of unskilled labor in the sector.

8. On Figure 1 they gain in terms of $X$, since the proportion by which their wage in $Z$ declines is less than the proportionate decline in the price of X. However, the reverse relationship is also possible.

9. Transferring the rents connected with the quotas to forelgn governments serves as a form of compensation that makes it easier for these governments to accept quantitative limits on their exports.

10. The ITC is already required to carry out such an assessment when the President decides to undertake a tariff-modifying negotiation with other countries. 


\section{REFERENCES}

Adams, Walter and Joel Dirlam (1984), "The Trade Laws and Their Enforcement by the International Trade Commission," in R.E. Baldwin (ed.), Recent Issues and Initiatives in U.S. Trade Policy. National Bureau of Economic Research Conference Report.

Baldwin, Robert E. (1976), "The Political Economy of Postwar U.S. Trade Policy," The Bulletin, 1976-4, New York University Graduate School of Business Administration.

Baldwin, Robert E. (1982), "The Political Economy of Protection," in J. Bhagwati (ed.), Import Competition and Response. Chicago: University of Chicago Press. Bhagwati, Jagdish N. (1980), "Lobbying and Welfare," Journal of International Economics, 14, 355-63.

Bhagwati, Jagdish and T.N. Srinivasan (1980), "Revenue-Seeking: A Generalization of the Theory of Tariffs," Journal of Political Economy, December, 1069-87. Brock, William A. and Stephen Magee (1980), "Tariff Formation in a Democracy," in John Black and Brian Hindley (eds.), current Issues in Commercial Policy and Diplomacy. London: Trade Policy Research Centre, 1-9. Cairnes, J.E. (1874), Some Leading Principles of Political Economy. London: Macmillan.

Feenstra, Robert C. and Jagdish N. Bhagwati (1982), "Tariff Seeking and the Efficient Tariff," in J.N. Bhagwati (ed.), Import Competition and Response. Chicago: University of Chicago Press, 245-61.

Findlay, Ronald and Stanislaw Wellisz (1982), "Endogenous Tariffs, the Political Economy of Trade Restriction, and Welfare," in Jagdish N. Bhagwati (ed.), Import Competition and Response. Chicago: University of Chicago Press, 223-34. Haberler, Gottfried (1936), The Theory of International Trade. London: William Hodge and Company. 
Hufbauer, Gary C. and Howard Rosen (1983), "Managing Comparative Advantage," unpublished paper.

Jackson, John H. (1984), "Perspectives on the Jurisprudence of International Trade," American Economic Review, May, 277-281.

Jacobson, Louis S. (1978), "Earning Losses of Workers Displaced from Manufacturing Industries," In Will1am G. Dewald (ed.), The Impact of International Trade and Investment on Employment. Washington, D.C.: U.S. Department of Labor, Bureau of International Labor Affairs.

Jones, Ronald W. (1971), "A Three-Factor Model in Theory, Trade, and History," in J.N. Bhagwat1, R.W. Jones, R.A. Mundell, and J. Vanek (eds.), Trade, Balance of Payments, and Growth. New York: American Elsevier Publishing Company, 3-21. Krueger, Anne 0. (1974), "The Political Economy of the Rent-Seeking Society," American Economic Review, 64, 291-303.

Magee, Stephen P. (1930), "Three Simple Tests of the Stolper-Samuelson Theorem," in P. Oppenheimer (ed.), Issues in International Economics. London: Oriel Press, 138-53.

Mayer, Wolfgang (1974), "Short-Run and Long-Run Equ1librium for a Small Open Economy," Journal of Political Economy, 82, 955-68. Mayer, Wolfgang (1983), "Endogenous Tariff Formation," University of Cincinnat1. Mussa, Michael (1974), "Tariffs and the Distribution of Income: The Importance of Factor Specificity, Substitutability, and Intensity in the Short and Long Run," Journal of Political Economy, 82, 1191-1203.

Neumann, George R. (1979), "Adjustment Assistance for Trade-Displaced Workers," in David B.H. Denoon (ed.), The New International Economic Order, New York: New York University Press. 
Richardson, J. David (1982), "Trade Adjustment Assistance Under the Trade Act of 1974," In J.N. Bhagwati (ed.), Import Competition and Response. Chicago: National Bureau of Economic Research - University of Chicago Press. Stolper, Wolfgang and Paul Samuelson (1941), "Protection and Real Wages," Review of Economic Studies, 9, 58-73.

U.S. Department of Commerce (1979), Survey of Current Business, 50, 4, 51-72. 